\title{
LEGAL INTERPRETATION OF POLISH TAX LAW BASED ON THE INSTITUTION OF REMUNERATION OF EXCESS PAYMENT - SELECTED ISSUES
}

\begin{abstract}
In order to achieve a desired effect of tax legal interpretation, its linguistic mechanisms are frequently insufficient. Elements of paralinguistic interpretation are more and more often indispensable. It applies inter alia when domestic tax law regulations must be verified in the light of the EU tax law. However, the study depict interpretative problems regarding the institution of remuneration of excess payments, which is regulated in Polish tax law. Considerations presented in this article confirm that legal interpretation of tax law is a complicated process. It is important to establish correct system connection between the analyzed legal regulations and other provisions, often contained in other legal acts. Moreover, it seems necessary to refer to the purpose-oriented interpretation of the law. Only then a chance for a satisfactory final result of the provision's legal interpretation can be guaranteed. What is more, such an effect will create an element being a part of a logically composed and arranged unity.
\end{abstract}

\section{Introduction}

Tax law regulations more often than not require a complex process of interpretation to be carried out. In order to achieve a desired effect of tax legal interpretation, its linguistic mechanisms are frequently insufficient. Elements of paralinguistic interpretation are more and more often indispensable. Such actions should be undertaken so that the results of such interpretation could, on the one hand, produce a clear effect, whereas on the other hand, elements should be logically related to other legal provisions. There are numerous reasons for such a state of affairs. What is more, they differ depending on the kind of law being subject to legal interpretation. The issue looks different when domestic tax law regulations, which must be verified in the light of the EU tax law, are subject of the analysis. Evaluating compliance of domestic tax law with the EU law, it is frequently not 


\section{Mariusz Popławski}

sufficient to carry out the analysis through the prism of individual provisions contained in legal acts created on the EU level. It results from the specificity of the EU law, which uses very general, and hence ambiguous, expressions. A problem with determination of the meaning of specified EU regulations may also be linked with the multiplicity of existing linguistic versions of the law. It may cause lack of adequacy in explanations of individual terms or notions. In consequence, it leads to evaluation of the compliance of specified domestic law regulations through the prism of frequently only generally outlined purposes set forth in preambles to individual acts of the EU law.

Moreover, paralinguistic interpretation plays a crucial role as far as tax law acts which fully remain within the scope of Polish fiscal jurisdiction are concerned. It refers to the acts which, as a rule, do not have to be evaluated through the prism of the EU law. There are many reasons for such a state of affairs. The following ones may be indicated therein. First of all, tax law regulates a complex matter. Consequently, a language describing it is often unable to include all issues related to this matter. Secondly, some attention should be paid to excessive casuistry of tax law acts. This mechanism makes tax law regulations barely legible. What is more, this method entails danger of committing mistakes by the legislator. Thus, one may easily lose his or her way in the web of provisions created by the legislator. Such connections occur not only within one legal act but they often form networks covering many tax law acts. The study will further depict interpretative problems regarding the institution of remuneration of excess payments, which is regulated, above all, in Art. 78 of ustawa z dnia 29 sierpnia 1997 - Ordynacja podatkowa (Dz. U. z 2012, poz. 749 j.t.) hereinafter referred to as the Tax Ordinance Act.

\section{A manner and legal form of decisions on remuneration of excess payment}

Remuneration of excess payment is subject to refund by virtue of the law. It means that the refund thereof does not have to be preceded by determination of the amount of remuneration by way of a decision. This opinion, however, does not result directly from any legal provision. Such a conclusion may be drawn from the system and purpose-oriented legal interpretation. In the case of ascertainment of basis for the refund of interest, a tax authority transfers the amount of interest a taxpayer is due to receive together with excess payment as part of financial-technical acts. 
This opinion is justified in jurisdiction (see: wyrok Wojewódzkiego Sądu Administracyjnego w Białymstoku z dnia 14 stycznia 2004, SA/Bk 35/03; wyrok Wojewódzkiego Sądu Administracyjnego w Łodzi z dnia 2 lutego 2005, I SA/Łd 176/04) and literature (Etel, 2011), where it is depicted that the refund of interest on ascertained excess tax payment a taxpayer is due and legible to receive may be regarded as a financial-technical act that does not require an administrative decision to be issued. The following arguments prove that there is no need for a tax authority to issue a decision on remuneration when it decides that a taxpayer is eligible to such a payment. The amount of interest can be calculated directly based on the application of provisions contained in the Act. Therefore an action involving a settlement of excess payment remuneration without issuing a decision will not violate taxpayer's interest. A settlement by way of the issue of a decision on remuneration of excess payment has, by design, a limited scope. A tax authority may ascertain relevance of remuneration without determining its amount at the same time. It results from the fact that interest payment is due on the day excess payment is paid out and not on the day its relevance is confirmed.

In some cases, however, a tax authority should resolve the issue related to remuneration of excess payment by way of the issue of a tax decision. The jurisdiction indicates that if, however, a tax authority refuses to make the payment to a taxpayer claiming that he or she is not entitled to it, then the tax authority should issue an administrative decision within this scope. (SA/Bk 35/03, wyrok Wojewódzkiego Sądu Administracyjnego w Warszawie z 13 kwietnia 2010, III SA/Wa 261/10). At the same time, it should not matter here whether a taxpayer demanded remuneration of excess payment as part of the proceeding. ${ }^{1}$ Moreover, it is emphasized that, as a rule, settling a case as far as its essence is concerned (it shapes the party's financial-legal situation), a tax authority is obliged to issue a decision - Art. $207 \S 2$ of Tax Ordinance Act (Dz. U. z 2012, poz. 749 j.t.). What is more, the essence of a case is not only the award of rights or imposition of duties but a refusal to acquire rights too. (wyrok Wojewódzkiego Sądu Administracyjnego w Białymstoku z dnia 14 lipca 2009, I SA/Bk 200/09). It is also rightly pointed out that a tax authority should issue an administrative decision within this scope not only when it entirely refuses to pay out interest to a taxpayer under Art. 78 of Tax Ordinance Act (Dz. U. z 2012, poz. 749 j.t.) but such settlement should also be issued when a tax authority calculates the amount of interest incorrectly, or does not pay out a full amount of interest due and a taxpayer applies for the payment of the whole amount of remuneration of excess payment he or she 


\section{Mariusz Poptawski}

is eligible to. (wyrok Wojewódzkiego Sądu Administracyjnego w Krakowie z dnia 14 lutego 2008, I SA/Kr 520/07). Another opinion that should also be regarded as relevant in its essence is the one according to which it is necessary to issue a decision on remuneration of excess payment each time the amount of such interest bears controversies between a taxpayer and tax authority, or when a tax authority issues a decision on ascertainment of excess payment, a decision on the amount of interest should be an element (part) of such a settlement, and if there are no bases whatsoever to issue a decision on excess payment, the amount of interest should be comprised by such a decision. (wyrok Wojewódzkiego Sądu Administracyjnego we Wrocławiu z dnia 19 czerwca 2006, I SA/Wr 604/05). The last two issues depicted above (remuneration of excess payment as an element of a decision on excess payment and a resolution on remuneration of excess payment by a separate decision complementing transfer of excess payment as part of financial-technical actions) should be found relevant when a tax authority has no intention of transferring remuneration of excess payment, or intends to transfer such consideration but in the amount that may evoke taxpayer's controversy.

Accepting the above presented opinions referring to situations when it is relevant to issue resolutions in the scope of remuneration of excess payments, it should be emphasized, nevertheless, that such resolutions are necessary solely when the legislator made the existence of interest dependent on specified circumstances whose ascertainment should be made by a tax authority. Under the Tax Ordinance Act, such a prerequisite exists in three provisions. The first situation occurs with regard to excess payment that arose in effect of the issue of a decision on a change, reversal or ascertainment of invalidity of tax decisions. In such cases excess payment is subject to refund together with interest as of the day the excess payment arose unless a tax authority has not contributed to the arising of the prerequisite of a change or reversal of the decision. The second situation occurs when a tax authority fails to issue a tax decision on ascertainment of excess payment within 2 months from the day an application for ascertainment of excess payment together with a corrected tax return was submitted. In this case excess payment is subject to interest as of the day the application for ascertainment of excess payment together with the corrected tax statement (tax return) was submitted unless a taxpayer, remitter or collector contributed to the delay of the decision's issue. The third situation occurs when excess payment is not returned within 2 months from the day a tax statement together with a corrected tax return with the revealed excess payment of tax was submitted. In this case excess payment is subject to interest from the day an application 
for ascertainment of excess payment together with the corrected tax statement (tax return) was submitted unless a taxpayer, remitter or collector contributed to the delay of the excess payment's refund.

It results from the analysis of the above-mentioned situations that a tax authority should refer to the issue of lack of remuneration of excess payment by way of a decision before the refund of excess payment in two cases indicated below.

The first situation accounting for justification by way of a decision on transfer of excess payment without interest occurs when excess payment arose in effect of the issue of a decision on a change, reversal or ascertainment of invalidity of tax decisions. A solution that should be adopted as relevant implies that in such as case a tax authority should undertake actions aiming at the analysis whether the tax authority has contributed to the arising of the prerequisite of a change or reversal of a tax decision. This authority should refer to this prerequisite by indication of its existence or lack of existence. Such actions will be justified when a tax authority will return excess payment paid directly on the basis of the reversed decision, or the decision whose invalidity has been ascertained. Moreover, such an action will be necessary when excess payment will be returned after the issue of a new decision. In this case excess payment is refunded in the amount equaling a difference between the tax paid and the tax resulting from this decision. Verification of the fact whether a tax authority has contributed to the arising of the prerequisite of a change or reversal of a tax decision in the first of the above-mentioned cases will occur as part of a separate proceeding concerning remuneration of excess payment. It will be necessary if a tax authority will not see any bases for transfer of interest as of the day the excess payment arose. In the second case, after the issue of a new decision, a tax authority should at the same time determine the amount of excess payment based on Art. 74a of Tax Ordinance Act (Dz. U. z 2012, poz. 749 j.t.), which is a difference between the amount paid and the amount resulting from the issued decision, as well as refer to the issue of interest mentioned in Art. $78 \S 3$ point 2 , particularly if it decides it will be undue. In other words, a tax authority should prove in such a case that there is lack of interest in connection with the fact that the tax authority has not contributed to the arising of the prerequisite of a change or reversal of the decision. It is reflected in the subject literature, where it is indicated that a settlement in the scope of the refusal to transfer remuneration of excess payment does not have be done in a separate decision. It may be one of the points of resolution of a case on excess payment in a decision on ascertainment or determination of excess payment. (Etel, 2011). 


\section{Mariusz Poptawski}

The second situation when a tax authority should refer to by way of a decision on lack of remuneration of excess payment occurs when excess payment arises in connection with an application for ascertainment of excess payment submitted together with a corrected tax return. This obligation will exist if within 2 months (from the day the above-mentioned application was submitted) a tax authority does not issue a decision on ascertainment of excess payment, or does not refund the amount of excess payment a taxpayer has been applying for within this period of time.

An element which constitutes protection of the taxpayer's right to receive remuneration of excess payments should be a possibility to demand initiation of proceeding in the matter of determination of interest. Jurisdiction draws attention to such a possibility emphasizing the fact that a taxpayer has the right to apply to a tax authority for a payment of correctly calculated remuneration of excess payment. If, however, a tax authority refuses to pay it, it is obliged to issue an administrative decision, which is subject to an appeal in the course of instance. (I SA/Kr 520/07). Nevertheless, a taxpayer should be entitled to this right after fulfilling two basic conditions. First of all, when a taxpayer has not received the amount of interest he or she is entitled to. Secondly, when the award of remuneration of excess payment depends on the circumstances of evaluation specified in Tax Ordinance Act. They are presented in the introductory part of this study. Nevertheless, one can come across contrary opinions in the light of which a taxpayer is not entitled to claim remuneration of excess payment in due amount in separate proceeding. (wyrok Naczelnego Sądu Administracyjnego z dnia 15 czerwca 2011, I FSK 894/10). Such an opinion is justified by the fact that in the case of a dispute between a tax authority and taxpayer on the amount of remuneration of excess payment, it will be crucial to refer to the legal basis of the decision awarding this amount, which could lead to an abortive statement according to which when making a decision on remuneration of excess payment, the authority would have a possibility of determining a different basis of its ascertainment or amount than in the decision on excess payment itself. It appears, however, that there are not any formal obstacles to claim consideration a taxpayer is eligible to within separate proceeding on remuneration of excess payment. Nevertheless, it is important to connect the basis of such a claim with the settlement concerning excess payment that has been issued before.

One may also come across opinions admitting a possibility of using other legal measures which a taxpayer may use when claiming remuneration of excess payment. The first one can regard a taxpayer raising the issue of lack of interest or transfer of this consideration in the amount lower than the 
due one in an appeal against the decision determining or ascertaining the amount of excess payment through raising the charge of non-determination or wrong determination of the period of excess payment's remuneration. (Etel, 2011). The second possibility can be questioning of the accuracy of calculated remuneration of excess payment also in a proceeding on counting any amounts paid in excess towards past due or current tax liabilities since, as a rule, excess payment together with interest, by way of a decision one is entitled to complain about, are counted towards past due or current tax liabilities - Art. 76 and 76a $\S 1$ of Tax Ordinance Act (Dz. U. z 2012, poz. 749 j.t.). Therefore a decision on counting excess payment should contain a decision on the amount of remuneration of excess payment. (I SA/Kr 520/07) The third possibility can be a request to complement a decision on excess payment under Art. 213 of Tax Ordinance Act (Dz. U. z 2012, poz. 749 j.t.) since it is indicated that when issuing a decision on excess payment of tax, a tax authority is also obliged to include interest thereto despite the fact that a taxpayer has not indicated it in the application. If a tax authority has failed to do it, it should complement the decision on the amount of calculated interest in the decision ascertaining excess payment. (wyrok Naczelnego Sądu Administracyjnego z dnia 8 listopada 2011, II FSK $833 / 10)$. What is more, it is emphasized that if a party rightly claims ascertainment of the acquisition of the right to remuneration they have acquired under the law according to principles specified in Art. $78 \S 1$ and $\S 3$ point 3 letter b and $\S 4$ of Tax Ordinance Act (Dz. U. z 2012, poz. 749 j.t.) from the organs, irrespective of the fact whether a tax authority knows the amount of interest or not, it is obliged to adjudicate about it, i.e. articulate that the ascertained excess payment will be subject to interest. Thus, if a tax authority has not itself contained a settlement confirming that the taxpayer will be refunded excess payment together with interest in the decision, the party has the right to demand completion of the decision issued towards them under Art. $213 \S 1$ of Tax Ordinance Act (Dz. U. z 2012, poz. 749 j.t.) as a case not concluding the entire administrative case. (wyrok Wojewódzkiego Sądu Administracyjnego w Gdańsku z dnia 16 maja 2012, I SA/Gd 200/12).

It should be emphasized that in some situations a taxpayer is entitled to a complaint about inaction or idleness of a tax authority in the matter of failure to transfer remuneration of excess payment. It refers to cases where such an obligation results from the force of law where there is no possibility of making any evaluation by a tax authority. A mechanism of the complaint about inaction or idleness is also applied when in the above-mentioned circumstances a tax authority transfers excess payment to a taxpayer but in the amount lower than the due one. 


\section{Remuneration of excess payment that arose in effect of the issue of a decision on a change, reversal or ascertainment of invalidity of tax decisions}

Excess payment that arose in effect of the application of extraordinary courses of verification of tax decisions is, as a rule, subject to interest as of the day the excess payment arose, that is, inter alia, from the day tax was paid on unduly or in the amount higher than the due one. This mechanism should be treated as a basic principle with, however, an important exception the legislator has introduced to it. It is applied when a tax authority has not contributed to the arising of the prerequisite of a change or reversal of a decision. In such a case, a tax authority returns excess payment without interest unless it fails to transfer it in due time. ${ }^{2}$ It means that when a tax authority has not contributed to the arising of the prerequisite of a change or reversal of a decision, remuneration of excess payment is due solely if there is a delay in the transfer of excess payment. In the case of the delayed transfer thereof, a taxpayer is eligible to interest for the period from the issue of the decision on a change or reversal of the decision to the day of the refund of the due amount to the taxpayer.

Taking the above into consideration it should be stated that in the case of excess payment that arose in effect of the issue of a decision on a change, reversal or ascertainment of invalidity of tax decision, it is a rule to return excess payment together with interest as of the day the excess payment arose. Whereas a burden of proof to indicate that a tax authority has not contributed to a change, reversal or ascertainment of invalidity of tax decisions burdens this authority. It is reflected in the legal interpretation of Art. $78 \S 3$ point 1 in connection with point 2 of Tax Ordinance Act. (Dz. U. z 2012, poz. 749 j.t.).

The question to be answered here regards understanding the prerequisite saying that a tax authority has not contributed to the arising of the premise of a change or reversal of a decision, as well as a way of its existence. Such contribution should be explained as a situation where a tax authority, even partially, bears responsibility for the issue of a faulty decision. ${ }^{3}$ At the same time, tax authority's liability for decision's defectiveness does not have to be exclusive. We should agree with the opinion according to which the contribution by a tax authority should be in the scope greater than other subjects participating in tax proceedings concluded with the issue of a faulty decision. ${ }^{4}$ What is more, such liability does not depend on the fault, or its lack, of the employees of the authority conducting the proceeding concluded by the issue of a defective decision. What is essential here is that either ac- 
tions or omission of the authority had a direct or indirect impact on the issue of the resolution which is then changed, reversed, or subject to ascertainment of invalidity. The jurisdiction depicts that the prerequisite referred to in the above-mentioned provision is not connected with protraction of tax proceeding (one cannot refer to this circumstance in the scope of a dispute regarding the amount of remuneration of excess payment). Moreover, this premise is connected with defects of a tax decision excess payment resulted from and not duration of the proceeding in this matter (wyrok Naczelnego Sądu Administracyjnego z dnia 13 sierpnia 2009, II FSK 425/08).

It seems that such situations may occur, most of all, when a decision is reversed during revived or reopened proceeding, or when its invalidity is ascertained. In the first situation, the contribution of a tax authority to the arising of excess payment may occur if the following circumstances were the bases for the decision's reversal: the decision was issued in result of a crime committed by an employee of the tax authority, or the decision was issued by an employee or tax authority which is subject to exclusion under Art. 130132 of Tax Ordinance Act (Dz. U. z 2012, poz. 749 j.t.), or the party did not participate in the proceeding not through their fault, or new important factual circumstances relevant to the case will be revealed, or new evidence the tax authority issuing the decision has not known about the existence of on the day the decision was issued will be revealed, or the decision was issued without obtaining an opinion of another body that is required by the law. If invalidity is ascertained, remuneration of excess payment may be due to a taxpayer particularly if the bases to issue such a settlement are situations when the decision was issued in breach of regulations on competence, or the decision was issued without legal grounds, or it was issued in gross violation of the law, or it regards the case that was already settled before by another final decision, or the decision was directed at a person that is no longer a party to the case, or the decision was unenforceable on the day it was issued and its unenforceability is of a permanent nature.

\section{Conclusion}

Considerations presented above confirm observations presented in the introduction therein related to the functioning of Polish tax law. Legal interpretation of this law is a complicated process. The interpretative process must frequently include paralinguistic mechanisms. In this context, it is important to establish correct system connection between the analyzed legal regulations and other provisions, often contained in other legal acts. More- 


\section{Mariusz Popławski}

over, it seems necessary to refer to the purpose-oriented interpretation of the law. Only then a chance for a satisfactory final result of the provision's legal interpretation can be guaranteed. What is more, such an effect will create an element being a part of a logically composed and arranged unity.

\section{N O T E S}

${ }^{1}$ In the judgment of Provincial Administrative Court in Bydgoszcz (Wojewódzki Sąd Administracyjny, WSA) (wyrok WSA w Bydgoszczy z 26 stycznia 2010, I SA/Bd 923/09) -, it was indicated that in the light of the Tax Ordinance Act provisions, remuneration of excess tax payment arises under the law itself, nevertheless, ascertaining excess payment, a tax authority is obliged to adjudicate about the interest thereon irrespective of the fact whether a taxpayer contained an application for remuneration of excess payment in the application for ascertainment of excess payment.

2 Pursuant to art. $77 \S 1$ point 1 and $\S 3$ of Tax Ordinance Act - (Dz. U. z 2012, poz. 749 j.t.), excess payment must be returned within 30 days from the day a decision on a change, reversal or ascertainment of invalidity of the decision was issued, or within 30 days from the day a new decision in this case was issued.

${ }^{3}$ It is confirmed in the linguistic meaning of the notion "to contribute", which is explained as being partly a cause of something, or influencing something.

${ }^{4}$ In the wyrok WSA w Białymstoku z 19 stycznia 2012, I SA/Bk 468/11, it was indicated that in Art. $78 \S 3$ point 2 of Tax Ordinance Act (Dz. U. z 2012, poz. 749 j.t.) the legislator did not reserve that contribution of a tax authority to the arising of the prerequisite of a change or reversal of a decision determining the amount of tax liability should be exclusive in nature. Therefore even when in the specified factual state a taxpayer himself could also have contributed to the arising of such a premise to some extent, for a final decision settling a case whether he or she is entitled to interest it is of crucial importance whether the tax authority has not mainly contributed to the arising of this premise of a change or reversal of a decision determining the amount of tax liability.

\section{R E F E R E N C E S}

Etel, L. (2011). Komentarz do art. 78 Ordynacji Podatkowej. In C. Kosikowski and others. Ordynacja Podatkowa. Lex.

Ustawa z dnia 29 sierpnia 1997 - Ordynacja podatkowa (Dz. U. z 2012, poz. 749 j.t.).

Wyrok Naczelnego Sądu Administracyjnego z dnia 13 sierpnia 2009, II FSK 425/08, LEX nr 527268.

Wyrok Naczelnego Sądu Administracyjnego z dnia 15 czerwca 2011, I FSK 894/10, LEX nr 990011.

Wyrok Naczelnego Sądu Administracyjnego z dnia 15 czerwca 2011, I FSK 894/19, LEX nr 990011.

Wyrok Naczelnego Sądu Administracyjnego z dnia 8 listopada 2011, II FSK 833/10, LEX nr 1027819. 
Wyrok Wojewódzkiego Sądu Administracyjnego w Białymstoku z dnia 14 stycznia 2004, SA/Bk 35/03, POP 2006, poz. 1.

Wyrok Wojewódzkiego Sądu Administracyjnego w Białymstoku z dnia 14 lipca 2009, I SA/Bk 200/09, LEX nr 550669.

Wyrok Wojewódzkiego Sądu Administracyjnego w Białymstoku z dnia 19 stycznia 2012, I SA/Bk 468/11, LEX nr 1108863.

Wyrok Wojewódzkiego Sądu Administracyjnego w Bydgoszczy z dnia 26 stycznia 2010, I SA/Bd 923/09, LEX nr 653560.

Wyrok Wojewódzkiego Sądu Administracyjnego w Gdańsku z dnia 16 maja 2012, I SA/Gd 200/12, LEX nr 1164445.

Wyrok Wojewódzkiego Sądu Administracyjnego w Krakowie z dnia 14 lutego 2008, I SA/Kr 520/07, LEX nr 468800.

Wyrok Wojewódzkiego Sądu Administracyjnego w Łodzi z dnia 2 lutego 2005, I SA/Łd 176/04, LEX nr 809192.

Wyrok Wojewódzkiego Sądu Administracyjnego w Warszawie z 13 kwietnia 2010, III SA/Wa 261/10, LEX nr 620074.

Wyrok Wojewódzkiego Sądu Administracyjnego we Wrocławiu z dnia 19 czerwca 2006, I SA/Wr 604/05, LEX nr 894564. 